\title{
(Not) Narrating the History of the Federal Republic: Reflections on the Place of the New Left in West German History and Historiography
}

\author{
Joachim C. Häberlen
}

\begin{abstract}
This article offers a critical engagement with narratives of the Federal Republic and with the role that the radical, extra-parliamentary left played within such narratives from the late 1960s into the 1970s. The article first discusses success stories of the Federal Republic that highlight the country's democratic achievements, as well as more critical accounts that focus on the emergence of a neoliberal regime of governmentality. In both accounts, the radical left plays a pivotal role, either because the left contributed to the democratization of the Federal Republic, or because it helped transform capitalism into its current neoliberal form. The article then challenges such narratives by suggesting an interpretation of the alternative left during the 1970s as a space for experimentation, and by highlighting the open-endedness of such experiments. Gaining a sense for this sort of experimentation means that the alternative left can be embedded neither in a narrative of successful democratization nor in one of neoliberal transformation. Finally, the article examines the urban revolts of 1980-1981, in particular ones that took place in West Berlin. Activists in these revolts celebrated the exuberant intensity of the moment but cared less about future changes. The challenge here is to understand the intensity of a moment that cannot be embedded in a narrative with a clear outcome. The article thus presents perspectives on the history of the Federal Republic that defy easy integration into any narrative framing.
\end{abstract}

Der Aufsatz bietet eine kritische Untersuchung üblicher Narrative bundesrepublikanischer Geschichte und der Rolle der außerparlamentarischen Linken in den späten 1960er und den 1970er Jahren in diesen Narrativen. Der Aufsatz diskutiert zunächst sowohl Erfolgsgeschichten der Bundesrepublik, die die demokratischen Errungenschaften des Landes betonen, als auch kritischere Erzählungen, die die Herausbildung einer neoliberalen Gouvernmentalität betonen. In beiden Erzählungen spielt die Linke eine tragende Rolle, sei es, weil die Linke zu einer Demokratisierung der Bundesrepublik beigetragen habe, sei es, weil sie bei der Verwandlung des Kapitalismus in seine gegenwärtige neoliberale Form halfen. Der Aufsatz hinterfragt diese Narrative indem er vorschlägt, die Alternative Linke der 1970er Jahre als einen Experimentierraum zu betrachten, und hervorhebt, dass der Ausgang solcher Experimente stets offen war. Einen Sinn für dieses Experimentieren zu gewinnen bedeutet, dass sich die Alternative Linke weder in narrative einer erfolgreichen Demokratisierung noch einer neoliberalen Transformation einbetten lässt. Schließlich untersucht der Aufsatz die urbanen Revolten 1980-81, insbesondere in West Berlin. Akteure in diesen Revolten zelebrierten die rauschhafte Intensität des Moments und scherten sich nicht um zukünftigen Wandel. Die Herausforderung besteht darin, diese Intensität des Moments zu erfassen, der sich erneut nicht in Narrative mit klarem Ausgang einbetten lässt. Der Aufsatz bietet mithin Perspektiven auf die Geschichte der Bundesrepublik, die sich einer einfachen Integration in jegliche narrative Rahmung entziehen. 
$\mathrm{T}$ HE history of the Federal Republic of Germany seems to be a success story. ${ }^{1}$ After the failed attempts to create a stable and enduring democracy in the revolutions of 1848 and then during the Weimar Republic, after the more or less authoritarian regime of the Kaiserreich and then the Nazi dictatorship, the western part of Germany at first—and eventually Germany as a whole - has turned into a stable and prosperous democracy. After the British referendum in June 2016 to leave the European Union (EU) and the election of Donald Trump as president of the United States in November of that year, German Chancellor Angela Merkel has even been presented as a last defender of Western liberalism. ${ }^{2}$ It is indeed a remarkable transformation: from a country that seemed to be the very antithesis of Western democracy during the first half of the twentieth century to its bulwark. To be sure, scholars of Imperial and Weimar Germany have painted a much more nuanced picture by now, highlighting the democratic practices and potentials of these societies. ${ }^{3}$ Yet, this does not change the basic story: West Germany seems to be an example of successful democratization and liberalization that shines particularly bright in comparison with the years of instability and destruction during the first half of the twentieth century. It is, to use Hayden White's terminology, a "romance," a heroic story of overcoming evil for good. ${ }^{4}$

In recent years, scholars have also presented more cautionary narratives that critically question the heroic stories of the Federal Republic's democratic success. While not putting the viability of Germany's democratic institutions in doubt, they draw attention to more microscopic forms of power that do not become visible by focusing on institutional or legal histories. Historians and sociologists working on questions of subjectivities have been most impressive in this regard. ${ }^{5}$ These scholars have explored the microscopic and often contradictory powers that guide how individuals form their selves emotionally, either mentally or bodily. While these "governments of subjectification" do not formulate explicit and strict rules that are to be followed, they nevertheless create a field of power that affects people. These studies offer a much less clear narrative. Scholars working in the field frequently emphasize paradoxes, tensions, and contradictions. If this literature follows a particular emplotment, in Hayden White's sense of the term, it is a satire: hopes that self-knowledge might lead to emancipation were disappointed, as the project of understanding the self only resulted in new forms of

\footnotetext{
${ }^{1}$ See, above all, Edgar Wolfrum, Die geglückte Demokratie: Geschichte der Bundesrepubik Deutschland von ihren Anfängen bis zur Gegenwart (Stuttgart: Klett-Cotta, 2006). See also, with a slightly more critical tone and additional references, Andreas Rödder, "Das 'Modell Deutschland' zwischen Erfolgsgeschichte und Verfallsdiagnose," Vierteljahrshefte für Zeitgeschichte 54, no. 3 (2006): 345-63.

${ }^{2}$ Alison Smale and Steven Erlanger, "As Obama Exits World Stage, Angela Merkel May Be the Liberal West's Last Defender," New York Times, Nov. 12, 2016.

${ }^{3}$ See Margret Lavinia Anderson, Practicing Democracy. Elections and Political Culture in Imperial Germany (Princeton, NJ: Princeton University Press, 2000); Kathleen Canning, Kerstin Barndt, and Kristin McGuire, eds., Weimar Publics/Weimar Subjects: Rethinking the Political Culture of Germany in the 1920s (New York: Berghahn, 2010); Peter Fritzsche, "Did Weimar Fail?," Journal of Modern History 68, no. 3 (1996): 629-56.

${ }^{4}$ Hayden White, Metahistory: The Historical Imagination in Nineteenth-Century Europe (Baltimore, MD: John Hopkins University Press, 1973), 8-9. For an excellent historical study making use of Hayden White's reflections, see James Krapfl, Revolution with a Human Face: Politics, Culture, and Community in Czechoslovakia, 19891992 (Ithaca, NY: Cornell University Press, 2013).

${ }^{5}$ See Andreas Reckwitz, Das hybride Subjekt: Eine Theorie der Subjektkulturen von der bürgerlichen Moderne zur Postmoderne (Weilerswist: Velbrück, 2006); Ulrich Bröckling, Das unternehmerische Selbst: Soziologie einer Subjektivierungsform (Frankfurt/Main: Suhrkamp, 2007); Pascal Eitler and Jens Elberfeld, eds., Zeitgeschichte des Selbst: Therapeutisierung — Politisierung-Emotionalisierung (Bielefeld: transcript, 2015).
} 
power. While there are opportunities for critique, always appearing in unexpected moments and always already in the process of waning, there is little hope that the struggle for emancipation might actually succeed in the end. ${ }^{6}$

The extra-parliamentary left of the 1960s and 1970s plays a crucial role in both narratives, though in different ways. ${ }^{7}$ On the one hand, scholars who present narratives of democratization debate whether the Federal Republic became a stable democracy because of or despite the student uprisings around 1968 and the subsequent wave of protests and terrorism (even though scholars of early West Germany have pointed out that processes of cultural liberalization and political democratization were well underway before the student protests of the 1960s)..$^{8}$ On the other hand, scholars writing about subjectivities have repeatedly emphasized that the countercultural and alternative milieus of the 1960s and 1970s played a decisive role in the development of an "entrepreneurial" or "creative-consumerist" self that characterizes the present. Values stressed in the alternative scene, such as emotionality or flexibility, have become, they argue, central features of culturally hegemonic forms of subjectivity. ${ }^{9}$ The irony is, of course, that the movements had started out to develop an alternative to capitalism, but ultimately contributed only to its transformation and strengthening, making this indeed a satirical story in Hayden White's sense.

This article presents an alternative perspective that differs with regard to temporal structure. Writing history in the conventional narrative mode that most histories follow implies developing a plot with a particular temporal structure: there is a clear beginning of the story, a development, and then a finish with some sort of resolution of conflict. Alternatively, the absence of such a resolution indicates the futility of all struggles, i.e., the case of satire. The important point, however, is that there is a particular temporal arc to the story, which usually ends in the present moment, with a stable democracy or with a neoliberal regime of subjectivity. The perspectives developed in this article do not follow this temporal structure and are, in this very specific sense, not narrative. To be clear, this is not to argue that the following accounts are any less constructed; moreover, one might well find literary forms that might serve as role models for presentations of history that follow different temporal structures.

To make this case, the article looks at a case study: the radical left from the mid-1970s to the early 1980s. ${ }^{10}$ It begins by examining how scholars have narrated the history of the extraparliamentary left and related it to more general narratives of the Federal Republic. The

\footnotetext{
${ }^{6}$ On the possibilities for criticism in this situation, see Bröckling, Unternehmerische Selbst, 283-97.

${ }^{7}$ The literature on "1968" is vast; see, e.g., Carola Fink, Philipp Gassert, and Detlef Junker, eds., 1968: The World Transformed (Cambridge: Cambridge University Press, 1998); Norbert Frei, 1968: Jugendrevolte und globaler Protest (Munich: Deutscher Taschenbuchverlag, 2008). Also see the special issue edited by Ingrid Gilcher-Holtey: 1968-Vom Ereignis zum Gegenstand der Geschichtswissenschaft. Geschichte und Gesellschaft, Sonderheft 17 (Göttingen: Vandenhoeck \& Ruprecht, 1998). For recent discussions of the historiography, see Quinn Slobodian, Foreign Front: Third World Politics in Sixties West Germany (Durham, NC: Duke University Press, 2012); Alex Vasudevan, Metropolitan Preoccupations: The Spatial Politics of Squatting in Berlin (Chichester: Wiley and Sons, 2016), 7-12.

${ }^{8}$ See the discussion in Joachim Scharloth, 1968: Eine Kommunikationsgeschichte (Paderborn: Wilhelm Fink, 2011), 14-20. On liberalization prior to 1968, see Ulrich Herbert, ed., Wandlungsprozesse in Westdeutschland: Belastung, Integration, Liberalisierung 1945-1980 (Göttingen: Wallstein, 2002).

${ }^{9}$ See Bröckling, Unternehmerische Selbst, 257-60; Reckwitz, Hybride Subject, 441-99. For a related argument regarding France, see Luc Boltanski and Eve Chiapello, The New Spirit of Capitalism (London: Verso, 2005).

${ }^{10}$ For a fuller discussion of the argument, see Joachim C. Häberlen, The Emotional Politics of the Alternative Left: West Germany, 1968-1984 (Cambridge: Cambridge University Press, 2018).
} 
article then develops two distinct nonnarrative perspectives. The second section proposes studying the alternative left as a space for experimentation. Noting that alternative leftists celebrated experimentation - culturally, sexually, spiritually, socially, and in other ways - is not novel. But we need to reflect on the narrative implications of taking this experimental aspect seriously. Leftists were engaged in multiple experiments, with multiple unforeseeable and unintended outcomes. To tell the story of the alternative left in terms of experimentation thus means that there is no more or less dramatic finish to the story; there is, to put it pointedly, no plot to recount. Finally, the article turns to the urban revolts of 1980-1981, a topic that has received much less attention than the protests around 1968. The article suggests understanding these later revolts as momentous (rather than transformative) events of a peculiar intensity. The challenge is to grasp this intensity of the moment, something that cannot, as we shall see, be embedded in a narrative structure.

\section{The Extra-Parliamentary Left in West German Historiography}

The left, and, in particular, the extra-parliamentary student left around 1968, has often been credited with a special role in the history of West Germany's democratization. According to sympathetic accounts, protesting students challenged and ultimately overcame the conservative and authoritarian mainstream of the early Federal Republic. Even though they did not achieve demands for a more radical form of democracy that would end capitalism, the argument goes, student protests did lay the foundations, in the long run, for a democratic political culture ingrained in everyday life and not limited to institutions. Perhaps most famously, political scientist Claus Leggewie has claimed that the protests of 1968 amounted to a "refounding" of the Federal Republic. ${ }^{11}$ Even the experience of terrorism during the German Autumn of 1977 has been interpreted in such terms. Karrin Hanshew has argued that, in responding to terrorism, conservatives came to realize that the democratic state had the means to deal with such a threat, and the extra-parliamentary left made peace with democracy and distanced itself from violence. ${ }^{12}$ While this "romantic" narrative stresses the Federal Republic's successful democratization, other equally sympathetic interpretations provide an incomplete, as it were, romantic account. They, too, highlight - and embracethe radical democratic impetus of the protests, but they are more skeptical with regard to the outcomes, for the radical potential of the student movement has still not yet been realized at the beginning of the twenty-first century. As Timothy Brown pointedly puts it, "1968 remains unfinished business in more ways than one."13 The fight for "light over darkness" that characterizes a romance is still ongoing. ${ }^{14}$

\footnotetext{
${ }^{11}$ Claus Leggewie, “1968 ist Geschichte,” Aus Politik und Zeitgescichte B 22-23 (2001): 3-6. For a similar approach, see Edgar Wolfrum, “'1968' in der gegenwärtigen deutschen Geschichtspolitik,” Aus Politik und Zeitgescichte B 22-23 (2001): 33; Detlef Siegfried, “Auf dem Weg zu einer zivilen Kultur: Die Westdeutschen zwischen Traditionalismus und 'Erlebnisgesellschaft,", in 50 Jahre Bundesrepublik: Daten und Diskussionen, ed. Eckart Conze and Gabriele Metzler (Stuttgart: Deutsche Verlags-Anstalt, 1999), 259.

${ }^{12}$ Karrin Hanshew, Terror and Democracy in West Germany (Cambridge: Cambridge University Press, 2012); idem, "'Sympathy for the Devil?' The West German Left and the Challenge of Terrorism," Contemporary European History 21, no. 4 (2012): 511-32.

${ }^{13}$ Timothy S. Brown, West Germany and the Global Sixties: The Antiauthoritarian Revolt, 1962-1978 (Cambridge: Cambridge University Press, 2013), 371. For a similar perspective, though one not limited to West Germany, see Gerd-Rainer Horn, The Spirit of '68: Rebellion in Western Europe and North America, 1956-1976 (Oxford: Oxford University Press, 2007).

${ }^{14}$ White, Metahistory, 9.
} 
Other scholars have looked at the extra-parliamentary left in less favorable terms. Still narrating West German history in "romantic" terms as a story of successful democratization, they have claimed that, rather than strengthening the Federal Republic's democratic culture, the protests of the 1960s and the terrorism of the 1970s endangered it. The Federal Republic became a stable democracy not because of, but despite these protests. ${ }^{15}$ In contrast to these sometimes highly politicized debates, recent scholarship has also questioned how big a role the protests played in liberalizing and democratizing West German (political) culture. "The rebels of 1968 stormed barricades that had been abandoned by their former defenders," Philipp Gassert notes. ${ }^{16}$ At stake in these debates is thus the place of the extraparliamentary left in the Federal Republic's history. The master narrative of this history remains the same, however: it is a "heroic" story of successful democratization.

But there are skeptical voices about this dominant master narrative. Scholars such as historian Nina Verheyen and linguist Joachim Scharloth have drawn attention to power relations in communicative forms that do not neatly fit into stories of democratization. In an insightful book, Verheyen has sought to historicize narratives of democratization by examining West Germans' “desire for discussing” (Diskussionslust), which was conceived as a more democratic form of communication than the commanding and conforming that, in the Americans' view, had characterized communication in Nazi Germany. But instead of taking this claim at face value and asking how the Federal Republic became a democratic society as a result of a new communicative culture, she has examined how Germans precisely came to believe that they had built a democratic society by communicating in a specific way. Verheyen has thus put into historical perspective the belief in discussing and in the power of rational arguments, which was so popular among leftist students in the 1960s. And, while Verheyen does see the merits in discussing, she is also keenly aware that discussions are, pace Jürgen Habermas, not spaces that are free of power relations: often, those who could hold out longer won the supposedly rational debates. ${ }^{17}$ Focusing on less formal forms of communication, Joachim Scharloth has made a related argument, claiming that students introduced informal modes of communication into West German culture. These forms of communication-addressing each other with the informal $D u$ and by first name, for example - seemed to be less hierarchical and, above all, a break with the rules of bourgeois mores. But Scharloth is deeply skeptical about claims that see these new communicative styles as liberating. Indeed, informal communicative styles followed their own rules, which could be as strict as formal ones. ${ }^{18}$ Both Scharloth and Verheyen thus express a certain skepticism vis-à-vis the standard success stories of democratization and liberalization. While they do not offer another master narrative, their accounts can be read as satires, insofar as they deconstruct the utopian projects of democratic and power-free forms of communication: their mode of presentation is ironic, and there is not even the possibility of a victory of "light over darkness."

\footnotetext{
${ }^{15}$ Kurt Sontheimer, So war Deutschland nie: Anmerkungen zur politischen Kultur der Bundesrepublik (Munich: C. H. Beck, 1999), 102; Götz Aly, Unser Kampf: 1968-Ein irritierter Blick zurück (Frankfurt/Main: S. Fischer, 2008).

${ }^{16}$ Philipp Gassert, "Narratives of Democratization: 1968 in Postwar Europe," in 1968 in Europe: A History of Protest and Activism, 1956-1977, ed. Martin Klimke and Joachim Scharloth (New York: Palgrave Macmillan, 2008), 315.

${ }^{17}$ Nina Verheyen, Diskussionslust: Eine Kulturgeschichte des "besseren Arguments" in Westdeutschland (Göttingen: Vandenhoeck \& Ruprecht, 2010).

${ }^{18}$ Scharloth, 1968.
} 
One can also read critical accounts of contemporary regimes of subjectivity as satires, even though authors frequently stress that they are not writing in a narrative mode. According to sociologists like Ulrich Bröckling and Andreas Reckwitz, individuals in the contemporary, neoliberal world are confronted with cultural scripts that instruct them how to shape their emotional, mental, and bodily selves. These scholars have examined the models of subjectivity that such scripts provide, emphasizing values that are constitutive for the postmodern self, such as autonomy, creativity, and self-realization. ${ }^{19}$ When these ideals first emerged, inter alia within the radical left and in the countercultures of the 1960s and 1970s, they were considered subversive and anticapitalist because they challenged and undermined the ideals of rationalist, industrial modernity. Leftists, that is to say, longed for personal autonomy in a society that seemed to require conformity and homogeneity. Yet, what started off as an emancipatory program turned into a new and powerful regime of capitalism: "Neoliberal political rationality does not govern against but with unfolded technologies of the self and thereby renders itself pleasurable," writes Sabine Maasen, "They always appear as technologies of freedom." 20 Such "satirical" narratives cast doubt on any claim that there was ever a real chance for emancipation. Sven Reichardt has made this argument most forcefully in his monumental study of the alternative left of the 1970s, which he sees as a regime of subjectification that required people to do certain things in order to be considered "authentic" (e.g., talking about their feelings). His assessment is bleak:

Within the left-alternative milieu, people had not only the right to live in a self-realized [selbstverwirklicht] fashion, but also the duty to render an account of themselves, and to convey these insights into the self to others ... The self-therapeutization was intended as a project for the liberation of the alienated individual, but it unfolded in the practice of the democratic panopticism a norming effect and became a management of the self. ${ }^{21}$

These accounts of the extra-parliamentary and alternative left in the Federal Republic work, if often implicitly, with different emplotments. For a long time, the majority functioned in a romantic mode, though there was no consensus about who represented "light" in the struggle over "darkness." Nor was there any consensus regarding the completion of these struggles. More recent scholarship offers an alternative to this approach by employing a satirical mode of emplotment. In this reading, the struggle for emancipation only led to new forms of self-disciplining, to a transformation of capitalism that could integrate and make use of the forces opposing it. Nowadays, creativity is no longer an authentic way of self-

\footnotetext{
${ }^{19}$ Bröckling, Unternehmerische Selbst; Reckwitz, Hybride Subject. See also, with additional references, Eitler and Elberfeld, Zeitgeschichte; Sabine Maasen et al., eds., Das beratene Selbst: Zur Genealogie der Therapeutisierung in den "langen" Siebzigern (Bielefeld: transcript, 2011); Maik Tändler, Das therapeutische Jahrzehnt: Der Psychoboom in den siebziger Jahren (Göttingen: Wallstein, 2016).

${ }^{20}$ Sabine Maasen, "Das beratene Selbst: Zur Genealogie der Therapeutisierung in den 'langen' Siebzigern: Eine Perspektivierung," in Maasen et al., Das beratene Selbst, 9. Emphasis in the original.

${ }^{21}$ Sven Reichardt, Authentizität und Gemeinschaft: Linksalternatives Leben in den siebziger und frühen achtziger Jahren (Berlin: Suhrkamp, 2014), 67-71. For further critiques of the liberalization paradigm along Foucauldian lines, see Jens Elberfeld, "Subjekt/Beziehung: Patriarchat—Partnerschaft-Projekt: Psychowissen und Normalisierungspraktiken im Diskurs der Paartherapie (BRD 1960-1990)," in Das Selbst zwischen Anpassung und Befreiung: Psychowissen und Politik im 20. Jahrhundert, ed. Uffa Jensen and Maik Tändler (Göttingen: Wallstein, 2012), 113-14; idem, "Befreiung des Subjekts, Management des Selbst: Therapeutisierungsprozesse im deutschsprachigen Raum seit den 1960er Jahren," and Marcel Streng, "Führungsverhältnisse im Hungerstreik: Ein Kapitel zur Geschichte des westdeutschen Strafvollzugs (1973-1985)," in Eitler and Elberfeld, Zeitgeschichte, 81-82, 145.
} 
expression in an alienated, capitalist world, but instead a requirement to succeed in this world. ${ }^{22}$ What these accounts have in common is a narrative arc that ends, more or less, in the present-be it the present of a stable, westernized liberal democracy, or the present of a neoliberal regime of subjectivity. The following sections look at two alternatives to this that function differently with regard to temporal structure. They represent an attempt to think about the history of the Federal Republic - or, to be more precise, about episodes in that history-without adopting a vanishing point that structures any narrative.

\section{Open Ends: Experiments in the Alternative Left}

The alternative left of the 1970s was a diverse and complex scene. Activists engaged in a variety of practices, from creating "consciousness-raising groups" (Selbsterfahrungsgruppen) to reviving traditions of the life-reform movement, from practicing yoga to practicing karate, from developing new forms of collective living to organizing independent youth clubs, from building self-managed companies to going on self-organized vacation trips. Emotions and bodies played a crucial role for both the political thinking and the political practices of the left. According to leftist critics, urban capitalism had erected an emotional regime that only allowed for fear and boredom, that isolated people from one another, and that did not permit the expression of feelings. ${ }^{23}$ Capitalism, leftists argued, forced men, in particular, to appear as fearless and rational beings who did not show any sympathy or solidarity toward other men. ${ }^{24}$ Facing this emotional plight, leftists developed a range of practices aimed at producing feelings that, they felt, were missing in modern, capitalist society. Focusing particularly on spatial aspects, one can interpret these practices as "emotional experiments" that sometimes succeeded in producing feelings, but sometimes also failed to do so. Speaking of "emotional experiments" emphasizes the constant process of trial and error in leftist attempts to overcome the emotional constraints of capitalism and to produce the feelings they desperately desired. ${ }^{25}$ What does conceptualizing the alternative left as a space for experimentation imply, then, in narrative terms?

At first sight, narrating an experiment, i.e., "trying out" new emotional practices, might look like narrating any other story in terms of the experiment's temporal structure: there is a clear beginning and a clear ending to the experiment, which might succeed, in the sense that it yields the results that those engaged in the experiment had hoped for- - or it fails because it does not yield such results. The temporal structure looks different, however, if we analyze the alternative left as a space for experimentation. It is no longer about the outcome of the experiment, but instead about a series of repeated and reworked experiments with multiple

\footnotetext{
${ }^{22}$ See Boltanski and Chiapello, Spirit.

${ }^{23}$ See, e.g., Detlef Hartmann, "Stadtknast-Knaststadt," Große Freiheit 43 (1981): 10-13; Ingolf Bonset, "Die Einsamkeit in den Städten," Das Blatt 84 (Dec. 24, 1976-Jan.13, 1977): 22-23. On critiques of modern urbanity, see also Christiane Reinecke, "Am Rande der Gesellschaft? Das Märkische Viertel—eine WestBerliner Großsiedlung und ihre Darstellung als urbane Problemzone," Zeithistorische Forschungen 11, no. 2 (2014): 212-34; Vasudevan, Metropolitan Preoccupations.

${ }^{24}$ See, e.g., Männergruppe Frankfurt, “Tod dem Patriarschismus [sic]: Es lebe der Mann!,” diskus 3 (1975): 26-28; anon., "Ein Mann und sein Profil (Cartoon)," Mannsbild (1976): 26. On fear, see also Frank Biess, "Die Sensibilisierung des Subjekts: Angst und 'neue Subjektivität' in den 1970er Jahren," WerkstattGeschichte 49 (2008): 51-72.

${ }^{25}$ See Joachim C. Häberlen and Maik Tändler, "Spaces for Feeling Differently: Emotional Experiments in the Alternative Left in West Germany during the 1970s," Emotion, Space and Society 25 (2017): 103-10.
} 
outcomes; there is no story to tell with a meaningful end. Writing the history of the alternative left in terms of experimentation does not therefore result in a new narrative for the Federal Republic. It is, rather, an attempt to regain a sense of the open-endedness of the situation.

The various consciousness-raising groups that were created provide an example of this kind of experimentation. ${ }^{26}$ Women's, men's, gay, and therapy groups emerged in numerous West German cities where a strong alternative scene existed. Some participants joined them in the hope of overcoming the emotional constraints of masculinity under capitalism — and in order to "strengthen feelings," as one man from Freiburg, who was looking for other men to form such a group, put it. ${ }^{27}$ Members of a Munich-based women's group claimed, for their part, that a group would give them an opportunity to "erase not only the wall between us and our bodies, but also the wall between us women." 28 Groups thus played a fundamental role in leftist efforts to transform their selves.

These groups published numerous and detailed reports that described what happened at their meetings, while also reflecting on members' feelings, on conflicts, and on the impact the sessions had on life outside the group. ${ }^{29}$ The participants mainly talked in these groups about their childhood, about their relations with parents and partners, about their feelings and sexuality, and, last but not least, about relations within the group. But just talking was not often enough. As one men's group from Heidelberg wrote, "Verbal power does not create emotionality." ${ }^{30}$ Groups therefore also engaged in a variety of bodily practices. Men shared moments of physical intimacy while sleeping in the same bed or cuddling with each other-which did not imply any homosexuality, as they were eager to emphasize- while women observed and explored their bodies and, in particular, their vaginas in order to develop a more positive relation to themselves. ${ }^{31}$

Participating in a group was anything but a purely joyous activity. In many cases, such accounts detail the pressures members faced and the tremendous conflicts that arose.

\footnotetext{
${ }^{26}$ On groups, see Maik Tändler, "Therapeutische Vergemeinschaftung: Demokratie, Emanzipation und Emotionalisierung in der 'Gruppe', 1963-1976," in Tändler and Jensen, Das Selbst zwischen Anpassung und Befreiung, 141-69.

${ }^{27}$ Martin Defren, “Männer-Gruppen in Freiburg, gibt's die?," Stadtzeitung für Freiburg 53 (Dec. 1980): 37. On men's groups, see Helmut Rödner, Männergruppen: Versuche einer Veränderung der traditionellen Männerrolle. Ursachen, Wege, Schwierigkeiten (Berlin: Editora Queimada, 1978); Autorengruppe, Männerbilder: Geschichten und Protokolle von Männern (Munich: Trikont Verlag, 1976); Till Kadritzke, "Bewegte Männer. Men's Liberation und Autonome Männergruppen in den USA und Deutschland, 1970-1995," in Feminismus in historischer Perspektive. Eine Reaktualisierung, ed. Feminismus Seminar (Bielefeld: transcript, 2014), 221-51.

${ }^{28}$ Anon., "Körperbewusstsein: Erfahrungen einer Selbsthilfe-Gruppe," Frauenjahrbuch (1976): 135-51. See also the translated text by a women's group from Sweden: "Was sollen Männer in Frauengruppen," Hundert Blumen 5 (n.d. [likely early 1973]): 7.

${ }^{29}$ Such reports were frequently published in left-wing magazines such as Das Blatt (Munich) or Carlo Sponti (Heidelberg), in gay publications such as Schwuchtel (West Berlin and Heidelberg), or in publications by men's groups such as Mannsbild (West Berlin).

${ }^{30}$ Die verbliebenen fünf aus der Männergruppe, "Männer—ohne Männlichkeit ratlos?," Carlo Sponti 20/ 21 (1976): 8-9.

${ }^{31}$ On men, see, e.g., Manfred et al., "Hickhack," Mannsbild (1976): 5-9; on women, see, e.g., Alice Schwarzer, "Die neuen Hexen," EMMA (May 1977): 6; anon., "Körperbewusstsein." See also Jane Freeland, "Women's Bodies and Feminist Subjectivities in West Germany," in The Politics of Authentic Subjectivity: Countercultures and Radical Movements Across the Iron Curtain, 1968-1989, ed. Joachim C. Häberlen, Mark Keck-Szajbel, and Kate Mahoney (New York: Berghahn, 2018), 131-50.
} 
Members of a gay group in West Berlin noted, for example, that the endless conversations were not just a source of frustration; they also perpetuated power relations rather than leading to some sort of "mutual understanding." Group members constantly yelled at each other, but they did not access their "most inner emotional world." In the end, they even worried that they might become suicidal. ${ }^{32}$ The men's group from Heidelberg highlighted the "general difficulty" that its "demand, to let more out during conversations $=($ sic) being more open, resulted in performance and competition pressure." 33 A seventeen-year-old girl from West Berlin who had joined a women's group organized by a young teacher had a similar experience: "I've felt group pressure, that is, everyone has to talk about herself, and that means that everyone has to have had certain experiences to be able to keep up in these conversations." ${ }^{34}$ In light of such accounts, Sven Reichardt has observed that, "what emerged was an almost pure culture of confession and avowal, which resulted in primarily talking about one's feelings and 'subjective affection' [subjektive Betroffenheit]." 35 Maik Tändler puts this idea more pointedly: "The therapeutic search for authenticity required submission to a strict system of emotional rules." 36 Such critical assessments imply a satirical narrative involving attempts at self-liberation that only resulted in new and strict rules. The struggle for personal transformation and liberation thus proved futile.

There is much to be said for such an interpretation. Yet, this emphasis on futile outcomes is not only one-sided: it also fails to account for the open and uncertain outcomes of the group activity experiments. The following story from a women's group in Munich illustrates this point. Already at conception and birth, they claimed, women developed a "hostility against the body" that was subsequently only strengthened by gynecologists and the pharmaceutical industry. Such hostility had made it difficult for them to "feel and experience ourselves in a sensual way (with eyes, ears, noses, hands, fingers, breasts, bellies, mouths, thighs, cheeks, and lips of all kinds)." The women thus set out to recover their bodies and feelings, to "re-include our body into our life (sensing-finding), and to live (love) with it (us) consciously in an emotional way." To that end, they wanted to understand their bodies better and, in particular, their menstrual cycle. They started by measuring their temperature on a daily basis, but soon added another thirty areas for self-observation, e.g., "feeling [English in the original] good or bad, dreamed, active, depressive, cried, thunder storm, thirsty, hungry, nervous, sad, and so on." In their initial euphoria, some women even started drawing an emotional curve, which they related to their temperature curve. Yet, this excessive self-observation quickly became a burden. In the hectic of everyday life, they forgot about measuring their temperature in the morning, and observing their emotional state on a daily basis could be highly depressing. "Every day hectic, depressive, sad, disrupted, relationship troubles. That's something we can only suppress." It is a bleak description, reminiscent of Reichardt's idea of "democratic panopticism," which only produced "norming"

\footnotetext{
${ }^{32}$ Anon., "SE-Panik,” HAW Info 21 (1976): 15-56.

${ }^{33}$ Männergruppe, "Männer-ohne Männlichkeit ratlos?"

${ }^{34}$ Ulla/Birgit/Susan/Sabine/Barbara, “'Ich möchte lernen, ich selbst zu sein.' Siebzehnjährige Oberschülerinnen schreiben über sich,” Kursbuch 47 (1977): 152.

35 "Subjkektive Betroffenheit" is a difficult term to translate; it roughly means "being affected by something." See Reichardt, Authentizität, 705.

${ }^{36}$ Tändler adds, however, that the "subcultural pluralization" of possible emotional expressions also led to a generally less strict emotional regime in West German society as a whole. See Tändler, Therapeutische Jahrzehnt, 349.
} 
effects. The attempt to develop a different relation to the body seems to have failed, then. But the women were well aware of the difficulties, and therefore decided to lower their demands, focusing only on really important criteria and summarizing their emotional situation every couple of days instead of daily. This seems to have worked, as many developed a more positive relationship toward menstruation. And, whereas they had previously thought about the bad smell or feelings of sickness, they now felt that it was "pleasant, despite the pain and psychic instability, to feel, to experience him-I mean, of course, her, that is, my period." 37

The group was not alone in modifying their practices in response to such frustrations. A certain Lothar, who had participated in a men's group in Munich, noted a feeling of "paralysis" after the first sessions: "I felt that we didn't talk with each other, but about each other." After "tenacious discussions," the group decided to "work through their relations," which caused two "big theoreticians" to leave the group because, Lothar claimed, they were afraid to show their feelings. Those who remained found the group rewarding, and at least Lothar was happy that he could "leave behind the paths of understanding and rationalizing" and just express whatever was bothering him "without any censorship." When he cried in front of the group, the others first reacted helplessly, but they then came and stroked and hugged him: "It was the first time that I allowed other men to do this, without consciously rejecting them." In the end, he had been able to develop a "new identity as a man," one that included an ability to show "feelings of sympathy, tenderness, vulnerability, jealousy, but also rage and aggression directly expressed" toward other men. ${ }^{38}$

These accounts suggest that consciousness-raising groups could result in personal transformations that many participants experienced as uplifting. Emphasizing these experiences is not to argue for a more positive - as it were, romantic - version of the story of successful selfliberation, however. It is also not to argue for a more balanced account that includes both positive (i.e., liberating) and negative (i.e., restricting) effects either. Rather, the point is to change the perspective and not understand the group experience from the "vanishing point" of self-liberation or self-imposed norms, but instead to look at them as continuously evolving experiments, as processes of trial and error in which activists produced a variety of feelings, ranging from frustration to enthusiasm. Approaching groups as experiments highlights in this way their immense emotional productivity, while, at the same time, attempting to develop a perspective that breaks with the temporal structure of conventional narratives.

A similar argument can be made with regard to the body politics of the alternative left. ${ }^{39}$ Much of the literature on bodies in the new left milieu has focused on sexuality and on the (problematic) attempts to develop different and more liberal forms of sexuality. ${ }^{40}$ But leftist body politics was not limited to sexuality. It developed both a more general critique of the bodily regime of capitalism, as well as practices that sought to disrupt this regime. According to leftist writers, capitalism fragmented bodies because specific tasks required only specific

\footnotetext{
${ }^{37}$ Anon., "Körperbewusstsein," 140-42.

${ }^{38}$ Lothar, "Ich freue mich, angefangen zu haben ...," Das Blatt 60 (Dec. 19 1975- Jan. 8 1976): 11-12.

${ }^{39}$ On bodies, see Reichardt, Authentizität, 629-720.

${ }^{40}$ See Dagmar Herzog, Sex after Fascism: Memory and Morality in Twentieth-Century Germany (Princeton, NJ: Princeton University Press, 2005); Brown, West Germany, 286-329; Peter-Paul Bänziger et al., eds., Sexuelle Revolution? Zur Geschichte der Sexualität im deutschsprachigen Raum seit den 1960er Jahren (Bielefeld: transcript, 2015); Joachim C. Häberlen, "Feeling Like a Child: Visions and Practices of Sexuality in the West German Alternative Left during the Long 1970s," Journal for the History of Sexuality 25, no. 2
} (2016): 219-45. 
parts of the body: genitalia (and only genitalia) for sex, thumbs and fingers (and only thumbs and fingers) for work. Writing in Autonomie, one of the most important theoretical magazines of the new left, Matthias Beltz argued, for example, that "the existence of this factory society destroys [zerstört] human beings into parts of the machine, into head, stomach, and sex." ${ }^{41}$ As Manne, the main character of Gerd-Gustl Müller's left-wing youth novel Der Job, described his own boring job: "Even a brain amputee [Gehirnamputierter] could do this. Arse, stomach, noggin, cock, and feet-none of that was necessary. Ready to be amputated. All you needed was your thumb and two fingers." 42 And author Lucy Körner argued in Ulcus Molle that children, who were naturally able to enjoy their bodily feelings, had to oppress those feelings or else face their parents' disapproval. As a result, children stopped "living their natural joy of life" and began to "cramp" (verkrampfen)..$^{43}$ Given this sad plight, leftists sought to develop a range of practices that would allow them to feel their bodies in a more intense and wholesome way. These included forms of sexuality that did not focus just on genitalia, but also on practicing yoga or karate, or on wild dancing. ${ }^{44}$ These practices were bodily experiments that, in some instances, succeeded in producing the intense feelings that many leftists longed for, but that failed to do so for others.

Reports about a "Leisure Time Alternative for Communes" that took place in KampLintfort near Duisburg in the summer of 1976, and that attracted about one hundred leftists, offer an example of such bodily experiments. ${ }^{45}$ The reports were, by no means, unanimously positive; some stressed joyous moments, others conflicts and frustration. Some attendees preferred to express feelings, including aggression, in a very direct manner, whereas others expressed thoughts in a more rational way. Frequently, those who could talk most loudly simply dominated discussions. But there were also more positive aspects. It was, as one participant put it, a "chamber for experimentation," where people lived "intensely" and did both "damaged" (beschädigt) and "beautiful" things. Bodily activities played a crucial role for this intensity. People went for a collective swim in a nearby lake, danced around nude in the rain, or painted each other's backs sitting in a huge circle. The collective outhouse was a challenge for some, though others enjoyed the possibilities for communication. These activities created, as one attendee put it, "beautiful moments where competition, performance pressure [Leistungskisten], and fear disappeared, where we felt free to be as we really are and did not have to be as we think others expect us to be." 46 At least for brief moments, the experiments seem to have yielded what participants had longed for: feelings free of the fear and competition that, in their minds, dominated the capitalist world.

The emphasis on peculiar moments of intensity that is typical for many of the texts that describe bodily experiences is noteworthy with regard to questions of narration. For leftist activists, it was not, or at least not primarily, the ultimate and lasting outcome of the struggles

\footnotetext{
${ }^{41}$ Matthias Beltz, “Abenteuer aus der Fabrik: Geschichten aus der Beziehung zwischen Linksradikalen und Arbeiterbewegung," Autonomie: Materialien gegen die Fabrikgesellschaft 9 (1977): 17.

${ }^{42}$ Gerd-Gustl Müller, Der Job: Roman (Munich: Weismann Verlag, 1977), 74.

${ }^{43}$ Lucy Körner, "Bioenergetik," Ulcus Molle 9/10 (1979): 21-23.

${ }^{44}$ See, e.g., Eva Goldmund, "Nachwuchs," Frankfurter Frauenblatt (Sept. 1980): 22; anon., "Karate," Lesbenpresse 2 (1975): 6.

${ }^{45}$ Anon., "FAK '76," Info BUG 129 (1976): 2; idem, "FAK ’76, Teil II," Info BUG 130 (1976): 3-4. See also Thommi, "FAK ’76: Freizeitalternative für Kommunen”; Elisabeth, "10 Tage Alternativismus FAK '76: Liebe-Freude-Shit—u. Freiheit," Carlo Sponti 22/23 (1976): 15-16.

${ }^{46}$ Anon., "FAK '76, Teil II."
} 
that mattered, but rather the production of fleeting moments of intensity. Leftists sometimes succeeded in creating such intense moments, but, in other situations, they failed. One group of women from Göttingen complained, for example, about "slow, gooey music [Schnulzenmusik]" at a women's only party that made them dance stereotypically in a "cutely female, gracefully charming" way, but that kept them from giving vent to their "energies (and aggressions)." 47 Writing about these (successful or failed) attempts to produce brief moments of intensity does not work in narrative mode. Narratives, as Hayden White described them, require a plot with a more or less clearly defined finale that structures the entire story. Exceptional moments of intensity do not constitute such a finale; there is no end to the story. They are, as it were, only fleeting sparks. Writing the history of such moments does not result in a new narrative, then, but in an attempt to write history in a different, nonnarrative mode. The following discussion of the urban revolts of 1980-1981 elaborates on this point.

\section{Intense Moments: The Revolts of 1980-1981}

In the spring of 1980, something unexpected happened: youth riots erupted in various cities in West Germany and in neighboring countries such as Switzerland and the Netherlands. In Amsterdam, squatters engaged in massive street battles with the police. ${ }^{48}$ In Germany, riots first erupted in Bremen on May 6, 1980, when a demonstration against a military recruitment ceremony ended with massive battles between protestors and the police. Then came Zurich, where a protest against a municipal policy to subsidize the local opera but not to give in to demands for an Autonomous Youth Center resulted in two nights of rioting on May 30-31, $1980 .{ }^{49}$ In June, the police evicted the occupants of the Dreisameck in West German Freiburg, an action that again led to violent protests. ${ }^{50}$ It took a while before the leftist scene in West Berlin joined the wave of revolts, but, when it finally happened in

\footnotetext{
${ }^{47}$ Anon., "Bericht über das nationale Frauenhaustreffen," Frauenzeitung 2 (1977): 17-23.

${ }^{48}$ On the revolts of 1980-1981, see Bart van der Steen and Knud Andresen, eds., A European Youth Revolt: European Perspectives on Youth Protest and Social Movements in the 1980s (Basingstoke: Palgrave Macmillan, 2016); Reichardt, Authentizität, 516-71; Freia Anders, "Wohnraum, Freiraum, Widerstand: Die Formierung der Autonomen in den Konflikten um Hausbesetzungen Anfang der achtziger Jahre,” in Das alternative Milieu. Antibürgerlicher Lebensstil und linke Politik in der Bundesrepublik Deutschland und Europa, 1968-1983, ed. Sven Reichardt and Detlef Siegfried (Göttingen: Wallstein, 2010), 473-98; Hanno Balz and Jan-Henrik Friedrichs, eds., "All we ever wanted ..." Eine Kulturgeschichte europäischer Protestbewegungen der 1980er Jahre (Berlin: Dietz, 2012); Vasudevan, Metropolitan Preoccupations, 86-132; Andreas Suttner, "Beton brennt": Hausbesetzer und Selbstverwaltung im Berlin, Wien und Zürich der 80er (Vienna: Lit-Verlag, 2011); Sebastian Haumann, “Schade, daß Beton nicht brennt ...” Planung, Partizipation und Protest in Philadelphia und Köln, 1940-1990 (Stuttgart: Franz Steiner, 2011); Georgy Katsiaficas, The Subversion of Politics: European Autonomous Social Movements and the Decolonization of Everyday Life (Oakland, CA: AK Press, 2006), 88-106; AG Grauwacke, Autonome in Bewegung: Aus den ersten 23 Jahren (Berlin: Assozation A, 2003), 34-86; Stefan Aust and Sabine Rosenbladt, eds., Hausbesetzer: Wofür sie kämpfen, wie sie leben und wie sie leben wollen (Hamburg: Hoffmann und Campe, 1981).

${ }^{49}$ Hanspeter Kriesi, Die Züricher Bewegung: Bilder, Interaktionen, Zusammenhänge (Frankfurt/Main: Campus Verlag, 1984); Heinz Nigg, ed., Wir wollen alles, und zwar subito! Die Achtziger Jugendunruhen in der Schweiz und ihre Folgen (Zurich: Limmat Verlag, 2001); Thomas Stahel, Wo-Wo-Wonige: Stadt- und wohnpolitische Bewegungen in Zürich nach 1968 (Zurich: Paranoia City, 2006); Sophie von Vogel and Lars SchultzeKossack, eds., Zür(e)ich brennt (Zurich: Europa Verlag AG, 2010); Mischa Brutschin, "Züri brännt," in Häuserkampf I: Wir wollen alles_Der Beginn einer Bewegung (Hamburg: Laika Verlag, 2012), 175-204.

${ }^{50}$ On Freiburg, see Volkhart Schönberg, "Freiburg: Bewegungen in den besetzten Häusern," in Häuserkampf I, 149-58.
} 
December 1980, the revolt was more intense, more violent, and longer lasting than in any other place. It was a time of "euphoric feelings of happiness" for the participants, as former activists from West Berlin put it. ${ }^{51}$ These revolts are interesting because of discussions about the temporality of politics that took place among activists, and, in turn, for the implications they have for conceptualizing the revolts as a nontransformative event. ${ }^{52}$ For protestors, only the radical and exuberant moment in the present mattered, not the future. The goal of the following discussion is thus not to inquire about the historical origins of such ideas or the lasting impact they had, or to contextualize such ideas in a postmodern moment-which are, no doubt, legitimate questions. Instead, it attempts to grasp the production of momentous and exuberant intensity during the revolts.

Temporality played a fundamental role for the activists' politics. ${ }^{53}$ Writing in the West Berlin magazine radikal, one group challenged a conventional temporal understanding of revolution: for old-style communist leftists, whom they criticized, "revolution is a fixed point, and beyond this, the realm of freedom supposedly exists; this idea is nothing but a consolation with a distant paradise, but we live here, now and today. Perhaps freedom is only the brief moment from the point when the cobblestone is picked up until it hits-that is, the moment of change, of transgression, of movement." 54 Scholars have repeatedly quoted this and similar phrases to discuss how protestors legitimized and romanticized violence. ${ }^{55}$ Yet, it is also worth thinking about the temporality of politics that the statement implies. According to a traditional understanding of politics, a revolution divides time into a before and after; the revolution is an event, clearly marked in time, that transforms everything, from a state of bondage into a state of freedom. Imagining such a revolution in the future was, so to speak, telling the history of a (future and potential) revolution with a "romantic" plot, i.e., as a struggle for liberation that would ultimately be successful. The anonymous authors developed, however, a different understanding of freedom and, by implication, of politics. What came after the moment of change did not matter; only the brief moments of transgression and movement were important. There is no grand finale to this story of revolution, only acts of transgression.

The anonymous authors were not alone in developing a different temporal understanding of politics. An activist writing as K. Ätzer for radikal described the exuberance of the riots that took place during a visit by the US president Ronald Reagan to West Berlin in June 1982.

\footnotetext{
${ }^{51}$ G.U., in discussion with the author, Berlin, Oct. 2011; U.W. and G.W., in discussion with the author, Berlin, Nov. 2011.

${ }^{52}$ For a sophisticated discussion of events as transformative moments, see William H. Sewell, Jr., Logics of History: Social Theory and Social Transformation (Chicago, IL: University of Chicago Press, 2005), 197-224; Robin Wagner-Pacifici, What Is An Event? (Chicago, IL: University of Chicago Press, 2017).

${ }^{53}$ See Joachim C. Häberlen, "Sekunden der Freiheit: Zum Verhältnis von Gefühlen, Macht und Zeit in Ausnahmesituationen am Beispiel der Revolte 1980/81 in Berlin,” in Ausnahmezustände: Entgrenzungen und Regulierungen in Europa während des Kalten Krieges, ed. Dirk Schumann and Cornelia Rauh (Göttingen: Wallstein, 2015), 195-213. Also see Lukas J. Hezel, “'Was gibt es zu verlieren, wo es kein Morgen gibt?' Chronopolitik und Radikalisierung in der Jugendrevolte 1980/81 und bei den Autonomen," in Zeitenwandel: Transformationen geschichtlicher Zeitlichkeit nach dem Boom, ed. Fernando Esposito (Göttingen: Vadenhoeck \& Ruprecht, 2017), 119-52. Hezel uses the same sources that I use, but he does not refer to my previous work, which has addressed questions of temporality and emotions in the revolts of 1980-1981.

${ }^{54}$ Anon., "Anarchie als Minimalforderung," radikal: Lieber explosives Chaos als kontrollierte Hochspannung 97 (1981): 10 .

${ }^{55}$ See Anders, "Wohnraum," 494-95; Sebastian Haunss, Identität in Bewegung: Prozesse kollektiver Identität bei den Autonomen und in der Schwulenbewegung (Wiesbaden: Verlag für Sozialwissenschaften, 2004), 122.
} 
There had been worries in "the scene" that the protests and riots might become utterly ritualized and thus not create a sense of transgression, but this author disagreed in retrospect: there was action, and "holy fuck, what an action!" It did not matter where "our rags weightlessly fly over the borders of order [Grenzen der Ordnung], the law is in flames. The moments in which I succeed in jumping out of the constraints of the usual impotence resemble each other: no matter whether it's December 12, Goltz-Street, Haig [all references to other riots] or another occasion - the feeling is the same."56 The excitement this author describes resembles what activist Tomas Lecorte wrote in an autobiographical account of his experiences as a "street fighter" during riots that took place in the spring of 1981: "Why would I care for risk and strategy, gains or material damages, given this feeling that the armored power is at the whim of my ridiculous stones! It should go on like this forever. It was better than any revolution." ${ }^{57}$ It was not the outcome that mattered for these activists, but the intensity of the moment. Indeed, their very sense of time changed during the revolt. The "movement," another anonymous author wrote in radikal in February 1982, had been an "eruption" that had made "time, clotted into an unbearable duration," explode. ${ }^{58}$ Inquiring about the (long-term) effects of these protest movements, about whether and how they contributed, for example, to changing political cultures or urban developments, would thus mean employing a temporal perspective that is at odds with what mattered for the activists themselves.

The Dutch activist group Agentur Bilwet theorized most thoroughly this understanding of the revolts as a peculiar event in time in their book Bewegungslehre. ${ }^{59}$ Though they were writing about the squatters' movement in Amsterdam in 1980, their reflections speak to the situation in West Berlin, as the editors of the book's German edition pointed out. ${ }^{60}$ Agentur Bilwet conceptualized a crucial moment of rioting - a riot that took place on July 3, 1980, in Amsterdam (riots on December 12, 1980, in West Berlin might be considered an equivalent) — as an event that "emancipated itself from the actors." In the event, the group argued that

the usual tree diagram of cause and effect is then abruptly replaced by a causality carrousel of incidents and stories, in which cause and effect turn out to be interchangeable ... [The event] is onetime, local, ecstatic. During the event, a compression of time occurs; it takes on an intensity whereby past and future fade into insignificance. It appears as the intrusion of the present into the plodding advance of history. ${ }^{61}$

According to Agentur Bilwet, riots, or at least particular riots, were moments of exuberant transgression from "culture" into "wilderness." 62 But such events were, by necessity, unique; they could not be repeated. Trying to turn an event into a movement that lasted de-intensified time. The perspective on time that Agentur Bilwet developed here clashes

\footnotetext{
${ }^{56}$ K. Ätzer, "Rhythmuswechsel, oder: Wenn wir alle unser revolutionäres Über-Ich mitbringen, dann sind wir schon doppelt so viele," radikal: Zeitung für den reißenden Absatz 106 (1982): 8-9.

${ }^{57}$ Tomas Lecorte, Wir tanzen bis zum Ende: Die Geschichte eines Autonomen (Hamburg: Galgenberg, 1992), 81.

${ }^{58}$ Anon., "Eingemachtes," radikal: Zeitung für unbeschwerte Stunden 103 (1982): 6.

${ }^{59}$ Agentur BILWET, Bewegungslehre: Botschaften aus einer autonomen Wirklichkeit (Berlin: Edition IDArchiv, 1991). For an English translation of the book, titled "Cracking the Movement," see https:// thing.desk.nl/bilwet/Cracking/ contents.html.

${ }^{60}$ Ibid., 9-10.

${ }^{61}$ Ibid., 168. (The quote is in the first chapter in the English version, "Special Movement Teachings.")

${ }^{62}$ Ibid., 42.
} 
with historians' usual understanding of time as a "sequence of actions" that unfold their meaning and consequences in complex contexts. ${ }^{63}$

But intense events did not simply happen. They were imaginatively anticipated in the late 1970s by leftist authors who had theorized ecstatic moments of transgression, thereby developing an understanding of politics that emphasized playfulness and irrationality. Groups such as the Hamburg Subrealists, a name reminiscent of the Surrealists of the 1920s, had celebrated the "revolutionary play of desire" that would be a never-ending "discovery and adventure." 64 Munich-based author and publisher Herbert Röttgen similarly described festivities, in his widely read book Vulkantänze, as moments when "groups, genders, and classes that live separately in everyday life establish numerous ties, interweave and interlock, until [reaching] the state of voluptuousness of communion, of homosexuality, of incest. All and any compulsiveness and efficiency thinking [Effizienzdenken] is melted away in a foaming and vibrating mixing pot." For Röttgen, only these exuberant festivities could spark revolutionary flames: "All great rebellions were less strategy, tactics, agitation, organization - they were, above all, a mass feast, a devil's ball that made all normalcies dance, a cornucopia of feelings." 65

Historical development, an issue that had been of central importance for traditional Marxist, left-wing politics, ceased to matter in the face of timeless feelings. As Rädli, another Munich author, put it in December 1977: "Long live the body of humankind and of earth, since it eludes the merciless machinery of history. Wishes are timeless; feeling has no history. If society stands at the abyss, only dancing against the grain of time will help." 66 Such texts created an imaginative knowledge of what would happen during intense moments, and of how they would feel. Radical activists knew what to expect and what to hope for in such situations.

Yet, and this is the paradox, such moments were unpredictable, and they had to happen unexpectedly. The riots in West Berlin on December 12, 1980, a date that became legendary within the scene, serve as an example. ${ }^{67}$ That day, rumors (which turned out to be false) spread that the police had evicted squatters at the Fraenkelufer in Kreuzberg. To protest the evictions, local activists spontaneously marched to nearby Kottbusser Tor, where heavy clashes ensued with the police who, at first, were forced to retreat. A man named Jürgen described what had happened to the newly established leftwing daily, taz: when he first heard about what was going on, he was in disbelief. Given years of a rather inactive left-wing movement, a riot in which protestors even seemed to have prevailed was unimaginable for him. Still, he went to Kottbusser Tor to see for himself what was happening. Once there, it rapidly dawned on him that, "this time, the powder keg had really exploded. The long, pent-up aggression, the result of a permanent meandering between threats and negotiations, [and] the daily pinpricks have created a situation that nobody can control." What he saw pushed him into a "different reality. A feeling of euphoria spreads; collectivization is well underway ... This night in Kreuzberg, social relations [die Verhältnisse] are turned upside down. The streets are full of people, barricades are being built; time and again groups of

\footnotetext{
${ }^{63}$ Sewell, Logics of History, 7.

${ }^{64}$ Anon., "Definition der Subrealisten," Revolte 15/16 (1976): 53-55.

${ }^{65}$ Herbert Röttgen and Florian Rabe, Vulkantänze: Linke und alternative Ausgänge (Munich: TrikontVerlag, 1978), 113-14.

${ }^{66}$ Rädli, "[Title Illegible]."

${ }^{67}$ Anon., "RZ und radi-kritisch betrachtet," radikal: Zeitung für Brigaden nach Europa 123 (1983): 15.
} 
people [are] discussing with one another." ${ }^{68}$ It was the sense of exuberant intensity that authors such as Röttgen and Rädli had imaginatively anticipated. When the riot finally happened, it happened unexpectedly. Unlike a "happening," a riot could not simply be staged. But the sense of timeless exuberance was anticipated.

These texts certainly suggest that at least some activists enjoyed the rioting, but interpreting this merely as a celebration of violence would miss something crucial. It was a peculiar form of violence they were celebrating: a confrontation with an opponent who was usually much superior. Moments of victory were often brief. When interviewed by the newsmagazine Der Spiegel, a seventeen-year-old boy who went by the name of Keule (club) explained that he had experienced a "feeling of freedom" when he saw the police running away, even if it was only freedom for fifteen minutes. What happened after these fifteen minutes was not important, added a man named Artur, because what mattered was that "you are, for once, free of fear." 69 A somewhat aestheticized account of the riots that took place during the visit of American Secretary of State Alexander Haig to West Berlin in June 1982, involving the "fighters of the erupting Sado-Marxist International," explains in stilted prose what created this sense of excitement and exuberance:

The crowd soon broke through the barriers to kill time for some eight hours, with some stones and joyous fires, and without any chiefs or prior agreements ... Beyond any categorical belonging, the proletarianized met during this game with fire ... The vandals created a zone that was partially liberated of any control, of any power and law, where encounters could develop, complicities, multifarious games against a world that controls all wishes and redirects them into production and consumption. The pleasure just to be there, to reconquer militantly and passionately a space and time that escaped at this moment any political or other maneuver. ${ }^{70}$

This was not simply a celebration of violence. The established order was suspended during the riot, at least for a brief moment. Unforeseen encounters became possible, and what mattered were wishes and games rather than the usual and predictable rationality. It was possible, as one rioter from Frankfurt put it, to be "unreasonable" during the riot. ${ }^{71}$ But this also implied that planned violence, including riots, could not produce such a sense of intensity. Indeed, riots ceased being attractive when they were ritualized, and the more clandestine forms of (violent) activism that began to replace riots did not yield similar feelings. ${ }^{72}$

Such feelings of intense exuberance were not limited to riots, even though these constituted moments of particular intensity. The entire spring and summer of 1981 was a period of "intoxication" (Rausch), one former squatter later explained. He and others enjoyed life in their squats, spending the day sunbathing on rooftops or dancing during improvised punk concerts. ${ }^{73}$ An article that appeared in the leftist magazine Traumstadt, likely in the early summer of 1981, provides a glimpse into left-wing, everyday life in West Berlin. The

\footnotetext{
${ }^{68}$ Jürgen, "Kreuzberg lebt," taz, Dec. 15, 1980, in Papiertiger Archiv Berlin, "Ordner Häuserkämpfe." See also Härlin, "Von Haus zu Haus," 1-5.

69"'SPIEGEL-Gespräch: 'Tränengas ist der dritte Bildungsweg,"' Spiegel, Oct. 24, 1983.

${ }^{70}$ Die Kämpfer der aufbrechenden sado-marxistischen Internationale, "Nicht stehenbleiben" (pamphlet), June 1982, in Papiertiger Archiv Berlin, "Ordner Anti-Nato Bewegung."

${ }^{71}$ Migro, "Römerberg: Ein besetztes Haus wurde geräumt," Vollautonom 200 (n.d. [likely Jan./Feb. 1981]): 6-7.

${ }^{72}$ See, e.g., Dr. Seltsam, "Käseklau und Bombenbau," radikal: Zeitung für Jagd aus Leidenschaft 104 (1982): 11.

${ }^{73}$ G.U., in discussion with the author, Berlin, Oct. 2011; U.W. and G.W., in discussion with the author, Berlin, Nov. 2011. See also Grauwacke, Autonome, 51. For a personal account, see Johann Christoph
} 
unnamed (presumably male) author usually got up late, at some point between $11 \mathrm{a} . \mathrm{m}$. and 12:30 p.m. He spent the day with a "dear woman" strolling through a park, a place of "ordered wilderness" where one could "forget oneself," but where it was also easier to exchange looks with others and enter into contact. He went to a demonstration, but its political purpose did not matter: it was simply a place to meet friends, to invent absurd slogans, and to enjoy a "joyful urban walk" (lustbetonter Stadtspaziergang) ${ }^{74}$ Life in West Berlin during the summer of 1981 (tellingly, the article does not specify the exact time the "events" are taking place) was characterized by a sense of timelessness, by a lack of structure and of political purpose; only playful desires mattered. Engaging in serious politics, or even reading about political movements, was simply boring, by contrast.

The revolts of 1980-1981 - which roughly lasted in West Berlin from December 1980 to September 1981 — were, these accounts suggest, a moment that stood out in time. They were a peculiar event, however, not because of their transformative quality, but rather because they created a distinct sense of intensity that set the revolt apart from "normal" times (this held true only for the activists, of course, not the authorities).$^{75}$ It is tempting to situate this celebration of momentous exuberance in a broader, poststructuralist moment. After all, it is indeed not by accident that these activists cited Michel Foucault's claim that revolts resemble fireworks, shot into the sky to disappear immediately. ${ }^{76}$ The main point, though, is to grasp the intensity of the moment, and to understanding therefore how the event was "dis-embedded" from a temporal narrative of causes and effects. The challenge is, in other words, to write the history of a moment and its production, rather than to develop a new historical narrative that asks about beginnings and endings, causes and effects.

\section{Conclusion}

There are good reasons to offer narratives of the Federal Republic. In times of growing skepticism about democracy and the future of European integration, "romantic" narratives of democratization and Westernization potentially help legitimize the democratic order and the European project. At the same time, "satirical" narratives that question stories of liberalization might help us develop a more critical perspective on the present. This article has not attempted to develop an alternative narrative. Rather, it proposes an alternative perspective that does not adhere to the temporal structure of conventional narratives. This should be seen as a supplement that addresses the blind spots of existing narratives, not as a replacement for them.

\footnotetext{
Wartenberg, Kreuzberg, K36, Leben in (der) Bewegung: Kreuzberg inside bis zum Fall der Mauer (Bockenem: Lühmann, 2003).

${ }^{74}$ Anon., "Liebe zur Stadt," Traumstadt 7 (n.d. [likely summer 1981]): 5-11. On the lure of West Berlin as a site of protest from the late 1960s to the early 1980s, see Belinda Davis, "The City as Theater of Protest: West Berlin and West Germany, 1962-1983," in The Spaces of the Modern City: Imaginaries, Politics, and Everyday Life, ed. Gyan Prakash and Kevin M. Kruse (Princeton, NJ: Princeton University Press, 2008), 247-75.

${ }^{75}$ For official expert perspectives on the revolt, see Jake Smith, "Apathy, Subversion, and the Network Sublime: Envisioning Youth Unrest in West Germany, 1980-87," in A Europan Youth Revolt: European Perspectives on Youth Protest and Social Movements in the 1980s, ed. Knud Andresen and Bart van der Steen (Houndmills: Palgrave Macmillan, 2016), 231-42.

${ }^{76}$ The radikal interviewer claimed to cite Foucault, but I have not been able to locate the actual quote in Foucault's work. See "Der Tod des politischen Subjekts: Interview mit Baudrillard," radikal: Fachblatt für alles, was Terroristen Spaß macht 126/127 (1984): 14-19.
} 
Narrating the history of the Federal Republic requires embedding events and developments into a (temporal) story that is structured by one or several vanishing points. The goal of this article has been to "dis-embed" events, as it were, by studying the practices of the alternative left as experiments, and by exploring the extraordinary emotional intensity of the revolts that took place in 1980-1981. The focus on experiments and moments is meant, conceptually, to shift attention away from outcomes, and to develop a sense of the range of possibilities that these actors explored in a process of trial-and-error. Historians of the Weimar Republic have argued, for a long time, for looking at Weimar as a "laboratory" of modernity, rather than as a prelude for Nazism. ${ }^{77}$ It is worthwhile to think about the Federal Republic, and particularly about the 1970s, in a similar way, i.e., as a laboratory of "postmodernity," and not as a prehistory of the present. ${ }^{78}$ After all, the dissolution of master narratives is the very signature of postmodernity. In that sense-to end on an ironic note-writing about the history of the Federal Republic in a nonnarrative way might in itself be part and parcel of a postmodern narrative.

UNIVERSITY OF WARWICK

\footnotetext{
${ }^{77}$ See Detlev Peukert, The Weimar Republic: The Crisis of Classical Modernity, trans. Richard Deveson (New York: Hill and Wang, 1993).

${ }^{78}$ For such a perspective, see Anselm Doering-Manteuffel, Lutz Raphael, and Thomas Schlemmer, eds., Vorgeschichte der Gegenwart: Dimensionen des Strukturbruchs nach dem Boom (Göttingen: Vandenhoeck \& Ruprecht, 2016); Konrad H. Jarausch, "Verkannter Strukturwandel: Die siebziger Jahre als Vorgeschichte der Probleme der Gegenwart," in Das Ende der Zuversicht? Die siebziger Jahre als Geschichte, ed. Konrad H. Jarausch (Göttingen: Vandenhoeck \& Ruprecht, 2008), 9-28.
} 